DOI: $10.19195 / 0137-1134.110 .4$

\title{
MAREK ZIRK-SADOWSKI
}

Uniwersytet Łódzki

\section{METODOLOGIE TEORII PRAWA A PROBLEM POLITYCZNOŚCI PRAWOZNAWSTWA. ASPEKT BEHAWIORALNY I INTENSJONALNY*}

1. Z historycznego punktu widzenia teoria prawa powstała pod koniec XIX wieku jako dyscyplina naukowa, niewątpliwie o zabarwieniu antyfilozoficznym i scjentystycznym, i z pewnością apolitycznym. Prace S. Korkunowa i L. Petrażyckiego miały na celu włączenie jej do ogólnego nurtu psychologii introspekcyjnej, który okazał się dla dyscyplin humanistycznych swoistym pomostem służącym wychodzeniu z kręgu filozofii. Usamodzielnienie naukowe dokonało się przez psychologizację pojęć prawnych i prawniczych. Jeszcze wyraźniej stało się to widoczne w realizmie amerykańskim, który posługiwał się metodami nauk behawioralnych. Za H.L. Hartem można dzisiaj powiedzieć, że tak rozumiana teoria prawa odwoływała się do tzw. postawy zewnętrznej wobec prawa poprzez korzystanie $\mathrm{z}$ twierdzeń ówczesnych nauk, niedawno wyłonionych z filozofii ${ }^{1}$.

2. Dopiero pod koniec XX wieku pojawiła się bardziej radykalna koncepcja teorii zewnętrznej, ujmowana jako tzw. badania interdyscyplinarne, nazywane czasami integracją zewnętrzną prawoznawstwa. Należy zauważyć, że tzw. podejście interdyscyplinarne jest również obecne w wielu nurtach teorii prawa i prawoznawstwie. Sformułowane w badaniach dwudziestowiecznych wezwania do pluralizmu metodologicznego z reguły wiążą się z podejściem behawioralnym, które chce nadać tzw. wymiar naukowy zagadnieniom prawnym i żąda zaniechania badań proponowanych przez wielkie systemy filozoficzne. Współwystępowanie elementów opisowych i ewaluatywnych jest w nich główną podstawą zarzutu nienaukowości. Z reguły temu modelowi badań przeciwstawiana jest teza, że wszelkie ich wyjaśnienia powinny się poddawać weryfikacji empirycznej, gdyż tezy, których się nie da zweryfikować w sposób empiryczny, są bez znaczenia poznawczego.

3. Na tym tle w XX wieku rozgorzała również dyskusja na temat naukowości prawoznawstwa. Była to kwestia istotna dla metody interdyscyplinarnego pra-

\footnotetext{
* Praca zrealizowana w ramach grantu: NCN Opus 9 2015/17/B/HS5/00495.

${ }^{1}$ H.L. Hart, Pojęcie prawa, przeł. J. Woleński, Warszawa 1998, s. 127-128.
} 
woznawstwa, gdyż nie chciało ono polemizować z filozoficzną tezą o odmienności epistemologicznej nauk humanistycznych i empirycznych. Jednocześnie wymagano od prawoznawstwa, aby zawarta w nim wiedza naukowa była rezultatem zastosowania sprecyzowanej metody naukowej w celu wyjaśnienia zjawisk. Taka wiedza ma mieć wysoką moc prognostyczną i eksplanacyjną. Twierdzenia naukowe charakteryzują się również tym, że dzięki ich wysokiej informacyjnej zawartości można je sprawdzić i potwierdzić. Są rezultatem działania w sposób metodyczny, czyli przez zastosowanie właściwej dla danej nauki metodologii badań2 Te dodatkowe wymogi, które miały wyróżniać teorię prawa w humanistyce, stały się powodem do podejmowania przez wielu teoretyków prawa różnych koncepcji naukowości w swych pracach. Dyskutowane był tak skrajne ujęcia, jak wizja nauki podjęta w tzw. Kole Wiedeńskim — zdania składające się na wiedzę naukową muszą opierać się bądź na zdaniach empirycznych (protokolarnych), bądź na bezpośrednich danych zmysłowych. Wyróżnikiem teorii naukowych w ujęciu pozytywizmu logicznego miała być indukcja — metoda wyprowadzania zdań ogólnych ze zdań opisujących pojedyncze doświadczenia. Eliminowało to jednak z zakresu naukowości rozważania oceniające i normatywne.

Później głównym przedmiotem zainteresowania były prace Poppera, dla którego warunkiem uznawania określonych twierdzeń za naukowe jest ich falsyfikowalność, a nie możliwość indukcyjnego wywiedzenia z obserwacji. Cechą pseudonauki (por. prawoznawstwo) jest w tym ujęciu używanie języka naukowego, chociaż twierdzenia nie są poddawane uznanym procedurom naukowym (falsyfikacji, intersubiektywnej sprawdzalności).

Wielość stanowisk metodologicznych, uzupełnionych wprowadzoną przez Kuhna kategorią paradygmatu, doprowadziła do pojawienia się w teorii prawa świadomości pluralizmu teoretycznego. Reakcje na tę wizję metodologii były różne: dogmatyzm, czyli bezkrytyczne akceptowanie jednej koncepcji nauki lub eklektyzm korzystający z rozmaitych i często niewspółmiernych teorii, w zależności od pojawiających się konkretnych problemów badawczych. W dużym stopniu te cechy miały tzw. wielopłaszczyznowe teorie prawa w ich tzw. metodologicznym ujęciu. Wreszcie obserwowano również postawę, za K. Mannheimem nazywaną ,przeliczaniem różnych perspektyw”, a polegającą na badaniu przydatności teorii w skutecznym wyjaśnianiu rzeczywistości społeczno-politycznej bądź przekonywającej interpretacji różnych jej aspektów ${ }^{3}$. Ostatecznym podsumowaniem tych sporów wydaje się teza A. Aarnio, że teoria prawa, podobnie jak inne nauki społeczno-humanistyczne, jest wiedzą wielo-paradygmatyczną z punktu widzenia zewnętrznego ${ }^{4}$. Można stwierdzić, że ostatecznie ówczesna teoria prawa opowiedziała się za postawą eklektyczną w metodologii interdyscyplinarnej teorii prawa.

\footnotetext{
2 Por. J. Apanowicz, Metodologiczne uwarunkowania pracy naukowej, Warszawa 2005, s. 15-26.

${ }^{3}$ W politologii na te podejścia wskazuje B. Krauz-Mozer, Teorie polityki, Warszawa 2005, s. 2

${ }^{4}$ Por. A. Aarnio, Philosophical Perspectives In Jurisprudence, Helsinki 1983, s. 10.
} 
4. Koncepcja teorii prawa kontynuująca tradycję zewnętrznego badania prawa jest aktualna do dzisiaj, ale już nie w postaci interdyscyplinarnej. Pojawiły się różne od interdyscyplinarnej koncepcji teorii prawa tzw. kognitywne badania nad prawem. Charakterystyczna jest tutaj próba stosowania o wiele lepiej określonej metodologii badań i budowa modeli zjawisk prawnych opierających się na metodach nauk empirycznych. Następuje w nich swoiste odniesienie zjawisk prawnych do tez nauk empirycznych, takich jak psychologia kognitywna, neurosciences, psychologia ewolucyjna, AI, ekonomiczne podejście do prawa ${ }^{5}$.

Mimo pewnego podobieństwa do znanej od końca XX wieku koncepcji interdyscyplinarnie zorientowanej teorii prawa, jest to inny model zewnętrznie ujmowanej teorii prawa. Nowe metody naukowe doprowadzają do przełamania dawnego podziału na kulturę oraz naturę i w rezultacie — do osłabienia podziału na wewnętrzne i zewnętrzne podejście do prawa ${ }^{6}$. Jak zauważa T. Pietrzykowski, tym razem chodzi o włączenie teorii prawa w „hierarchię eksplanacyjną”, w której wyjaśnienia zjawisk zachodzących na poziomach najgłębszych (np. wyjaśnienia zawarte w fizyce) wyznaczają dopuszczalność wyjaśnień zjawisk zachodzących na poziomach wyższych (jak np. biologicznym) ${ }^{7}$. Rozwój wiedzy o człowieku i zjawiskach kulturowych nie dąży w tej sytuacji ku dwutorowości poznania, w ramach której Dilthey wskazywał na swoistość nauk przyrodniczych i nauk o duchu. Wiedza o człowieku sięga do głębszych wyjaśnień i zajęcia odpowiedniego miejsca „u szczytu tej hierarchii” przez wyjaśnianie humanistyczno-społeczne. Okazuje się bowiem, że na obecnym etapie rozwoju nauki wyjaśnienia z głębszych poziomów „,wreszcie osiągają punkt, w którym mają coś interesującego do powiedzenia na temat zjawisk wyższego poziomu"8.

Inaczej niż w programie interdyscyplinarnej teorii prawa $\mathrm{z}$ lat 70 . ubiegłego stulecia, nauki empiryczne nie wspomagają tylko jurysprudencji, lecz tworzy się ,wertykalna" integracja wiedzy, ostatecznie lokująca nauki humanistyczno-społeczne na jej szczycie, ale podstawy wiedzy mają charakter fizyczno-biologiczny ${ }^{9}$. W ten sposób dochodzi do zbudowania sieci wyjaśnień naukowych, które obejmują całą organizację materii i specyficznych własności, zjawisk czy procesów ${ }^{10}$. Ponieważ nie chodzi tutaj o redukcjonizm, użycie terminu hierarchia wyjaśnień jest niewłaściwe. Dawałoby to iluzję jakiejś antropocentrycznie ujętej epistemologii podbudowującej

5 Szerzej na ten temat, choć sceptycznie, pisze W. Załuski. Por. idem, Nauki kognitywne a filozofia prawa, [w:] Integracja zewnętrzna i wewnętrzna nauk prawych, cz. I, red. M. Zirk-Sadowski, B. Wojciechowski, T. Bekrycht, Łódź 2014, s. 175-187.

6 Temu zagadnieniu T. Pietrzykowski poświęcił pracę Intuicja prawnicza. W stronę zewnętrznej integracji teorii prawa, Warszawa 2012.

7 Por. ibidem, s. 23 i podane tam przypisy.

8 Cyt. za: ibidem, s. 24.

9 Ibidem, s. 24.

10 Ibidem, s. 25. 
nauki humanistyczne, w tym prawoznawstwo. Termin „sieć wyjaśnień” może jest w tej sytuacji lepszą propozycją ${ }^{11}$.

5. W polskiej teorii prawa ten nowy typ zewnętrznie budowanej teorii prawa, nazywany nieco mylnie kognitywistyką prawniczą, jest uważany za znacznie zaawansowany, jednolity paradygmat naukowy ${ }^{12}$. Jego główną cechą ma być przełamanie tradycyjnych podziałów na naturę i kulturę, naturalizm i antynaturalizm, racjonalizm i irracjonalizm oraz oferowanie jednej wizji nauki, w której wyjaśnianie prawa jest częścią ogólnego modelu naukowości.

Należy jednak zauważyć, że tzw. podejście interdyscyplinarne jest również nadal obecne w teorii prawa i prawoznawstwie. Sformułowane w badaniach dwudziestowiecznych wezwania do pluralizmu metodologicznego z reguły wiążą się $\mathrm{z}$ podejściem behawioralnym, które chce zagadnieniom nadać tzw. wymiar naukowy i żąda zaniechania badań proponowanych przez wielkie systemy filozoficzne. Współwystępowanie elementów opisowych i ewaluatywnych jest w nich główną podstawą zarzutu nienaukowości. $Z$ reguły modelowi filozoficznemu (mentalistycznemu) przeciwstawiana jest teza, że wszelkie ich wyjaśnienia powinny się poddawać weryfikacji empirycznej, gdyż tezy, których się nie da zweryfikować w sposób empiryczny, są bez znaczenia poznawczego.

$\mathrm{Na}$ tym etapie brakuje dysput na temat modelu naukowości prawoznawstwa. Akceptuje się po prostu metody naukowe tych nauk. Z reguły korzysta się z ogłoszonych tez empirycznych. Następnie na podstawie tych danych buduje się modele instytucji prawnych lub zjawisk prawnych. Szczególnie jest to widoczne w ekonomicznym podejściu do prawa, które korzysta z modeli ekonometrycznych ${ }^{13}$.

6. Tego typu teorii prawa trudno przypisać uwikłanie polityczne. Z opisanym zewnętrznym podejściem do prawa najlepiej współdziała polityczność, która oparta jest na władzy jako rodzaju siły czy przemocy. W koncepcji Webera władza ma substancjalny charakter, polega na sytuacji urzeczywistniania wewnątrz stosunku społecznego własnej woli, również mimo oporu. Władza pojmowana jest jako zdolność realizowania przez daną osobę swojej woli, obrony własnych interesów. Wiąże się ona ze stosowaniem siły w celu wymuszenia zgodnych z własnymi zamiarami zmian w świecie zewnętrznym. Takie sformułowanie funkcjonuje również w literaturze politologicznej, która na podstawie koncepcji Weberowskiej definiuje władzę jako możność podejmowania decyzji politycznych istotnych dla społeczeństwa, przy jednoczesnej możliwości użycia zorganizowanej przemocy w celu wymuszenia danego zachowania. $Z$ tego punktu widzenia trwałość władzy zależy od jej trwałości w czasie stanu sytuacji kryzysowej, czyli zagrożenia. Jest tu oczywiście miejsce na wykorzystanie w budowie polityczności na-

11 Terminów „hierarchia wyjaśnień”, „ukoronowanie wiedzy” T. Pietrzykowski używa, korzystając z sugestii zawartych w cytowanych przez siebie pracach.

12 Sceptycznie na ten temat pisze W. Załuski, op. cit., s. $176 \mathrm{n}$.

13 Jako przykład zob. pracę M. Goleckiego, Między pewnościa a efektywnością. Marginalizm instytucjonalny wobec prawotwórczego stosowania prawa, Warszawa 2011. 
rzędzi pochodzących z nauk opartych na modelu racjonalności instrumentalnej. Podobnie jak w zewnętrznie zorientowanej teorii prawa, dąży się do prawidłowo określonych celów i wykorzystania $\mathrm{w}$ ich osiąganiu wiedzy naukowej na temat zjawisk społeczno-ekonomicznych. Ograniczenia wyboru wynikają tylko z ograniczeń moralnych lub innych systemów wartości. Taką koncepcję budowania prawa przedstawił w polskiej literaturze J. Wróblewski, a w politologii K. Opałek ${ }^{14}$. Wzajemna relacja teorii prawa i teorii polityki w obu modelach kształtuje się na poziomie metateorii. Metateoria prawa wykorzystuje jako narzędzie budowy prawa metateorię polityki, a metateoria polityki używa metateorii prawa. Chodzi bowiem o efektywność techniczną w obu dziedzinach, do uzyskania której nie jest potrzebna jakakolwiek hermeneutyka. Relacja teorii prawa i polityki rozpoznawanej przez teorię polityki ma więc charakter przedstawiany przez stary ideał nauki interdyscyplinarnej. Celem budowania relacji jest wzajemne wykorzystanie osiągnięć, a nie budowa jednej wiedzy o świecie, która ma przyświecać naukom kognitywnym.

7. Oprócz wspomnianych nurtów rozwijała się zawsze teoria prawa rozumiana jako część prawoznawstwa, ujmowanego jako nauka praktyczna i służąca dogmatykom oraz jurysdykcjom. Stosując wspomniane na wstępie Hartowskie rozróżnienie podejścia wewnętrznego i zewnętrznego, można powiedzieć, że ta część teorii prawa była zorientowana na postawę wewnętrzną wobec normy prawnej. Próbowała ująć sens normy, choć metodami językowo-logicznymi, jak nazywał to J. Wróblewski. Kluczowym artykułem w rozwoju tak rozumianej teorii prawa w polskiej literaturze prawniczej stała się praca T. Gizbert-Studnickiego i K. Płeszki na temat teorii wykładni prawa ${ }^{15}$.

Autorzy wskazali na dwa aspekty wewnętrznie rozumianej teorii prawa: wymiar intensjonalny i ekstensjonalny. Choć wspomniana praca dotyczyła bezpośrednio teorii wykładni, jej tezy można rozciągnąć na całą teorię prawa ujmującą prawo z punktu widzenia wewnętrznego. W pewnym uproszczeniu można powiedzieć, że intensjonalnie ujmowana wewnętrzna teoria prawa zajmuje postawę, którą Hart określił jako krytyczno-refleksyjną. Wraz z rozwojem prawniczej filozofii analitycznej, a w szczególności logik deontycznych, wyłoniło się również ekstensjonalne ujęcie prawa ujmowanego jako zjawisko językowe.

W ujęciu intensjonalnym teoria prawa ostatecznie zwróciła się ku teoriom argumentacji i dyskursu prawnego, traktując je jako źródła sensu pojęć prawnych. W ujęciu ekstensjonalnym tym pojęciom nadaje się tylko zakresy, rezygnując $\mathrm{z}$ bezpośredniego ingerowania $\mathrm{w}$ ich treść ${ }^{16}$. Tę formę teorii prawa realizują za-

14 Por. J. Wróblewski, Model racjonalnego tworzenia prawa, „Państwo i Prawo” 1977, nr 11; oraz K. Opałek, Zagadnienia teorii prawa i teorii polityki, Warszawa 1986.

15 Por. T. Gizbert-Studnicki, K. Płeszka, Dwa ujęcia wykładni prawa. Próba konfrontacji, „Zeszyty Naukowe Uniwersytetu Jagiellońskiego. Prace z Nauk Politycznych” 20, 1984, s. 17-27.

16 Ten problem opisał K. Płeszka w swej książce Wykładnia rozszerzająca, Warszawa 2010. 
tem najlepiej sformalizowane ujęcia logik prawniczych, najczęściej pojawiające się w formie logik deontycznych ${ }^{17}$.

Ujęcia intensjonalne różnią się stopniem dbałości o doprecyzowanie sensów pojęć, a w skrajnej wersji zbliżają się do dywagacji analityczno-hermeneutycznych prowadzonych na gruncie filozofii i nauk humanistycznych. Poprzez odwoływanie się do orzecznictwa są jednak ściśle związane z praktyką prawniczą i często przez nią wykorzystywane jako uzasadnienie orzeczeń i decyzji stosowania prawa. Za J. Leszczyńskim można stwierdzić, że uczestniczą w argumentacji mającej na celu tzw. pozytywizację prawa ${ }^{18}$.

8. Wracając do tytułowego problemu, można powiedzieć, że właśnie w intensjonalnej postaci teoria prawa zbliża się często do argumentacji politycznej i zadawane jest jej pytanie o obecność w niej wartości pochodzących z tej części kultury. Tylko bowiem w próbie bezpośredniego uchwycenia sensów składających się na prawo i odrzuceniu teorii prawa $\mathrm{w}$ jej wersji metateoretycznej jest możliwe bezpośrednie zderzenie z sensami politycznymi.

Jedynym ograniczeniem metodologicznym dla intensjonalnego ujęcia prawa, pochodzącym z samego prawoznawstwa, jest pozytywizm prawniczy. Niezależnie od licznych przemian, które dokonały się ostatnio na gruncie pozytywizmu prawniczego, należy uznać za słuszną tezę, że pozytywizm jako metoda jest głównym źródłem rozwoju prawoznawstwa ${ }^{19}$. Odrzucając założenia metafizyczne przyjmowane w prawoznawstwie bazującym na wartościującej definicji prawa, pozytywizm odwołał się do zjawisk językowych jako podstaw poznania prawa. Dokonał samodzielnego zwrotu językowego, niezależnego od zwrotu językowego obwieszczonego później w filozofii. Podobnie jak konstrukcja woli, podmiotu, związku przyczynowego itd., również i język został przedstawiony „prawniczo”, jako kategoria prawnicza używana w poznaniu prawa. Można zaryzykować tezę, że na gruncie prawa ustawowego jest ona zbliżona do koncepcji zarysowanej w Polsce przez K. Ajdukiewicza ${ }^{20}$. Okazała się ona odporna na rewolucje, które wydarzyły się na gruncie filozofii analitycznej, a których rezultaty nie funkcjonują dzisiaj w praktyce prawniczej. Dzięki pozytywizmowi, który stał się metodą dogmatyk i praktyki prawniczej, ujawniła się odrębność naukowa teorii prawa. Jej rozwój dokonywał się głównie w opozycji do modelu działającej praktyki. Teoria starała się ukazywać ukryte założenia koncepcji analizy języka, proponowanej w pozytywizmie prawniczym, i głównie przez zaangażowanie w filozofię języka wkroczyła w spory toczące się w innych naukach humanistycznych i społecznych (problem naturalizmu). Zaowocowała również wielością paradygmatów badania prawa,

17 Por. ibidem.

18 Por. J. Leszczyński, Pozytywizacja prawa w dyskursie dogmatycznym, Kraków 2010.

19 Por. L. Morawski, Podstawy filozofii prawa, Torun 2014, s. 31 n.

20 Por. L. Leszczyński, B. Wojciechowski, M. Zirk-Sadowski, Wyktadnia w prawie administracyjnym, [w:] System prawa administracyjnego, t. 4, red. L. Leszczyński, B. Wojciechowski, M. Zirk-Sadowski, Warszawa 2012, s. 147 n. 
uznając pozytywizującą praktykę prawniczą tylko za obiekt badawczy, a nie za wzorzec poznawania prawa ${ }^{21}$. Ostatecznie dokonało się usytuowanie teorii prawa w pozycji krytycznej wobec pozytywistycznie zorientowanych dogmatyk prawniczych. Intensjonalna teoria prawa ujawniła komunikacyjne, dyskursywne i argumentacyjne założenia dogmatyk, które w tych naukach prawnych zostały ukryte we wspomnianych konstrukcjach języka prawnego, i cech podmiotu prawa.

9. Okazało się, że ten model teorii prawa najłatwiej nawiązuje łączność z polityką opartą na koncepcji władzy, której istotą jest komunikowanie się wewnątrz społeczeństwa. Źródła tej koncepcji władzy dostrzegamy przede wszystkim w refleksji H. Arendt, dla której władza to nie narzucanie woli innym, ale zdolność łączenia się ludzi w działaniu bez użycia przymusu. Istotą władzy jest tylko jej potencjalny charakter. Władza w tym ujęciu nie jest czymś gotowym, wypełnionym koniecznymi własnościami, jakimś bytem. Jest raczej typem stosunków międzyludzkich, który może się aktualizować, ale który nigdy w pełni nie może się zmaterializować, istnieje tylko jako proces aktualizowania ${ }^{22}$. Podczas gdy moc jest naturalną cechą jednostki rozpatrywanej osobno, władza rodzi się między ludźmi, gdy działają oni razem ${ }^{23}$. Domaga się zgody, zgodności wielu woli i intencji, która może zaistnieć jedynie w przestrzeni publicznej24.

Istotne jest tutaj pojęcie przestrzeni publicznej, czyli miejsca, w którym dokonuje się uprawomocnienie władzy, ale w warunkach koniecznego pluralizmu poglądów.

Zdaniem Arendt pluralność poglądów jest zjawiskiem nieusuwalnym z kondycji ludzkiej. Przemoc może jedynie doprowadzić do jej ukrycia. Co więcej, $\mathrm{i}$ jest to najistotniejsze z punktu widzenia polityki prawa, w ludzkim doświadczeniu nie ma takich treści, które dałyby podstawę do tezy, że ćwiczenie ludzkich umysłów poprzez dyskusję może zaprowadzić nas do jednej prawdy. Możemy jedynie kreować dyskusję nad publicznymi sprawami i w ten sposób przekładać swoje poglądy na interesy oraz niejako ustępować w procesie wyważania tych interesów ${ }^{25}$. Nie prowadzi to jednak do wspólnego poglądu, jednej prawdy. Sfera publiczna jest zatem rodzajem zobowiązania do osiągania wystarczającego kompromisu, potrzebnego tylko dlatego, że ludzie różnią się w poglądach. Dyskusja uniwersytecka nie zastąpi polityki, tak jak rozum teoretyczny nie zastąpi rozumu praktycznego i zdolności osądzania.

${ }^{21}$ Kilka tez przedstawionych w tej części pracy jest uogólnieniem tez, które sformułowałem tylko w odniesieniu do nauk administracyjnych w pracy Metodologia nauk prawnych na tle metodologii prawoznawstwa, [w:] Koncepcja systemu prawa administracyjnego, red. J. Zimmermann, Warszawa 2007, s. 617-633.

22 Tak wyjaśnia ten problem J.P. Hudzik, Wykłady z filozofii polityki, Lublin 2002, s. 86 n.

23 H. Arendt, Kondycja ludzka, Warszawa 2000, s. 219.

24 Por. J.P. Hudzik, op. cit., s. 87.

25 M. Canovan, Arendt, Rousseau and human pluralisty in politics, „Journal of Politics” 1983, nr 45, s. 296-297. 
Optymalny model osiągania takiego kompromisu Arendt znajdowała w greckim polis, jako tym ideale, z którego wychodzi wspomniana formuła życia politycznego. Analizując to jeszcze głębiej, możemy dostrzec wizję polityki, która przeciwstawia się makiawelicznej czy leninowskiej koncepcji władzy. Jest to władza, która postrzega samą siebie nie w przemocy, tylko w pewnym sposobie rozmawiania, w pewnym sposobie porozumiewania się, który rodzi intencje, rodzi wspólną wolę. Można powiedzieć, że sfera publiczna staje się intersubiektywnym polem tworzenia sensów i wspólnych symboli. Równie wyraźnie pogląd ten jest obecny w Szkole Frankfurckiej, a przede wszystkim w myśli J. Habermasa ${ }^{26}$.

10. Władza w ujęciu komunikacyjnym naprowadza na pojęcie dyskursywnej (komunikacyjnej) relacji między teorią prawa a polityką. Obie te sfery nie są już oparte na myśleniu ze środka na cel, ale, ale uzależniają ważność wszelkich norm, „od zgody tych, którzy jako osoby, których rzecz dotyczy, uczestniczą w racjonalnych dyskursach"27. W tym duchu zaczęto odbudowywać zagubioną przez pierwotny pozytywizm łączność między kategoriami prawnymi i politycznymi. Dokonywało się to głównie przez budowanie pomostu ku anglosaskiej koncepcji prawa opartej na politycznej koncepcji wolności i środków jej ochrony przez prawo ${ }^{28}$.

W przeciwieństwie do wspomnianego podejścia zewnętrznego badanie naukowe nie polega tutaj na porównywaniu prawa i polityki z wybranym teoretycznym modelem świata i konstruowaniu wskazówek, jak ten model urzeczywistnić w prawie i polityce. Celem badań staje się poszukiwanie uprawomocnienia dyskursywnego istniejących więzi i stosunków społecznych, co oznacza uzależnienie ontologii życia społecznego od wymiaru aksjologiczno-hermeneutycznego ${ }^{29}$.

Pojęcia polityczne i prawne znajdują uzasadnienie jedynie w kontekście, w którym się je tworzy i stosuje. Według wspomnianego już K. Mannheima dokonuje się ,przeliczanie różnych perspektyw” — ustalanie przydatności teorii w skutecznym wyjaśnianiu rzeczywistości społeczno-politycznej bądź przekonywającej interpretacji różnych jej aspektów.

Wartości i porządki aksjologiczne ukazują swoją dyskursywnie ustalaną treść zarówno w prawie, jak i w polityce. Pojawia się interpretatywność obu zjawisk, czyli dyskursywne budowanie znaczeń i symboli w przestrzeni społeczno-politycznej. Sposób ich określania i dyskutowania decyduje o ich odbiorze przez audytoria, a następnie o konfiguracji w świadomości społecznej.

26 Por. J. Habermas, Faktyczność i obowiązywanie, przeł. A. Romaniuk, R. Marszałek, Warszawa 2005, s. $166 \mathrm{n}$.

27 Ibidem, s. 173.

${ }^{28}$ Por. dwie najważniejsze w tym aspekcie polskie prace: M. Smolak, Uzasadnienie sadowe jako argumentacja z moralności politycznej. O legitymizacji władzy sędziowskiej, Kraków 2003; oraz L. Morawski, Główne problemy wspótczesnej filozofii prawa. Prawo w toku przemian, Warszawa 1999.

29 A. Jabłoński, Filozoficzna interpretacja życia społecznego w ujęciu Petera Wincha, Lublin 1998, s. 118. 
Nazywanie praktyk społecznych, a następnie korekta tych nazw i ich znaczeń w dyskursach wiąże się z odpowiedzialnością za sam dyskurs. Jak się okazuje w obserwacji dyskursów politycznych, można jednak dokonać wyboru koncepcji dyskursu. Wbrew dotychczasowym przekonaniom forma konsensualna dyskursu, czyli służąca ostatecznemu porozumieniu co do treści symbolicznych, nie musi być jedyna.

12. W sytuacji toczącego się społecznego konfliktu pojawiają się spory dotyczące kształtu dyskursu, zakresu, a także prawomocności i stałości rezultatów. Agonistyczne koncepcje dyskursu odrzucają możliwość ostatecznej zgody, w tym między kategoriami prawnymi i politycznymi. Interpretacyjność rodzi nawet pokusę i możliwość zastąpienia konsensualnej formy dyskursu formą agonistyczną, czyli założeniem immanentności konfliktu w demokracji. Proponują rozszerzenie demokracji przez włączenie nawet skrajnych podmiotów politycznych. Mają koncentrować one się wokół skrajnie przeciwnych kwestii światopoglądowych. W ujęciu dyskursywnym odbija się Schmittowska idea wroga, choć czasami łagodzona przez przedstawianie dwóch stron debaty jako przeciwników funkcjonujących w tych samych ramach systemowych, ale skazanych na ostateczne niezrozumienie i opierających się na emocjonalnym wymiarze dyskursu ${ }^{30}$.

$\mathrm{W}$ ten sposób jednocześnie dochodzi do ujawnienia pozoru transcendentalno-apriorycznej istoty reguł dyskursu konsensualnego i idealnej sytuacji komunikacyjnej. Okazuje się on formą historyczną, związaną z przekonaniami uczestników procesu interpretacyjnego.

Ofiarą tej zmiany staje się również prawo i jego teoria. Skrajnym przejawem jest z reguły podważenie wartości walidacyjnej norm konstytucyjnych i w ramach agonistycznego dyskursu podważenie pozytywistycznego przekonania o obowiązywaniu konstytucji na rzecz odwołania się do kategorii społeczno-politycznych i momentu historycznego.

Wbrew pozorom interpretacyjne wizje rzeczywistości społeczno-politycznej i intensjonalność teorii prawa, przejawiająca się tylko w argumentacyjnym objaśnianiu pojęć prawnych, doprowadziły do powstania zjawiska przeceniania pozycji społecznej jako źródła siły argumentu. Zrodziły one aktywizm sędziowski, a w sferze politycznej deliberatywny model demokracji, ale tym samym uzmysłowiły możliwość prezentowania dowolnej formy dyskursu, jako praktyki interpretacyjnej zjawisk społecznych.

13. Można postawić tezę, że z analitycznego punktu widzenia ostatecznym celem dyskursu w ujęciu agonistycznym staje się zatem uzyskanie przewagi siły illokucyjnej dla prezentowanego argumentu. Nie ma tu miejsca na takie punkty odniesienia, jakie zawierała idealna sytuacja komunikacyjna. Uzyskanie większej mocy argumentu politycznego niż siła illokucyjna argumentu prawnego daje

30 Por. Ch. Mouffe, Paradoks demokracji, przeł. W. Jach, M. Kamińska, A. Orzechowski, Wrocław 2005, s. 22, 33, 118-122. 
bowiem bezpośrednią korzyść w postaci zwykłego przekonania większej liczby wyborców. Jest to w dyskursie agonistycznym ostateczna nagroda dla dyskutanta, którą można uzyskać bez wykazywania słuszności lub prawdziwości głoszonych tez. Zwycięstwo tego typu dyskursu oznaczałoby odrzucenie również metodologii intensjonalnej teorii prawa, opierającej się na konsensualnej koncepcji dyskursu, i uznanie jej za całkowicie konwencjonalną, choć działającej w formie performatywnej, ale z pewnością nie transcendentalno-hermeneutycznej ${ }^{31}$. Nastąpiło zatem ostateczne zerwanie z obiektywnością i prawdą.

Okazało się jednocześnie, że w tym modelu możliwe jest specyficzne zjawisko, dostrzegane dzisiaj przez wielu: demokracja, która obraca się przeciwko sobie i unicestwia prawo, atakując tzw. rule of law. W tych warunkach przestaje działać triada: demokracja, rule of law, respekt dla praw człowieka.

Skutki zerwania związku między argumentacją filozofii i teorii prawa a metafizyką najbardziej stały się odczuwalne w przedstawionych zjawiskach. Chyba od tego momentu nastąpiła utrata kryteriów obiektywnego wyboru między różnymi wartościami, w tym również politycznymi.

Skutkiem umocnienia się takich poglądów stał się zanik tradycyjnej roli filozofii w kulturze. Nowa forma kultury, czyli kultura masowa oparta na wzorcach tworzonych w mediach i czerpanych z mediów, nie mogła oczywiście przyswoić filozofii i jej kategorii jako wzorca argumentacji, natomiast zawłaszczyła argumentację polityczną, która chętnie korzystała z mediów, traktując je jako sposób wpływania na wyborców. Po zerwaniu więzi polityki z metafizyką związek polityki i kultury masowej był już bardzo ułatwiony. Nie istniały bowiem teoretyczne przeszkody do zaakceptowania przez politykę form dyskursu i argumentacji kultury masowej nastawionej na doraźny efekt społeczny.

Można zapytać, czy jesteśmy skazani na sprzeczność tych dwóch stanowisk, z których jedno łączy ściśle metafizykę i politykę, a drugie je oddziela lub nawet sobie przeciwstawia, albo czy jest możliwe uratowanie pozycji filozofii prawa $\mathrm{w}$ polityce, ale bez zawłaszczania przez nią polityki?

Odpowiedź na to pytanie sama w sobie jest pewną filozofią. Od tego paradoksu związanego z brakiem metafilozofii nie ma ucieczki. Można jednak odwołać się do ewolucji samej polityki i myśli politycznej, wskazującej niejako te związki z filozofią, które są dla niej do zaakceptowania. Przeważa z pewnością myśl polityczna, iż nie można odpowiedzialnie twierdzić, że dostrzegany w metafizyce ład rzeczywistości wyznacza ścieżki naszego postępowania. Jedynie tomiści poważają się dzisiaj na takie twierdzenie. Dominuje pogląd Kanta, że domena wolnej woli, domena postępowania i współdziałania, jest zasadniczo sferą autonomiczną

31 Problem ten zasygnalizował i szeroko przedstawił jego skutki A. Bator, nazywając to zjawisko ,pragmatycznie zorientowaną teorią prawa”: Polityczne interpretacje analitycznej teorii prawa, [w:] Integracja zewnętrzna ..., s. 11-39, a w szczególności s. 12. 
i zależy od naszych przekonań o tym, co dobre i złe (tylko dlatego mówienie o odpowiedzialności, w tym politycznej, ma sens).

Polityczna praktyka państwa liberalno-demokratycznego odrzuca ideę metafizyki, która wyznaczałaby bieżące cele polityki. Jest to bowiem państwo neutralne światopoglądowo, traktowane współcześnie jako najlepsza ze znanych i sprawdzonych form rozumnej praktyki władzy, państwa i polityki ${ }^{32}$. Teza ta wynika z praktyki politycznej XX wieku, a nie z uzasadnienia filozoficznego. Państwo liberalno-demokratyczne, stojąc niejako poza sporami filozoficznymi, odrzuca społeczną praktykę polityki opartą na myśleniu substancjalnym, treściowym, którego istotą jest wybór „lepszego" światopoglądu. Myślenie substancjalne zastępuje się w nim myśleniem o formach praktyki politycznej, wskazując warunki realizacji wszelkich treści społecznych, i orzekaniu o ewentualnym zakazie realizacji określonych celów ${ }^{33}$.

Akceptacja koncepcji władzy i polityki państwa liberalno-demokratycznego, która odgrywa dzisiaj rolę ideału politycznego urządzenia państwa, sugeruje, że demokracja stoi przed filozofią w porządku myślenia.

Tezę tę akceptuje wiele nurtów filozoficznych. W koncepcji filozofii liberalizmu J. Rawlsa demokracja jest procedurą rozwiązywania konfliktów i uzgadniania interesów, wyprzedzającą wszelkie inne stanowiska, które można zająć wobec rozdziału dóbr ${ }^{34}$. Podobnie R. Rorty uważa, że demokracja, gwarantując ludziom wiele ważnych praw oraz możliwości realizacji potrzeb, sama w sobie jest wystarczająco dobrze ugruntowana i nie wymaga żadnej filozoficznej wizji natury ludzkiej ${ }^{35}$.

Takie stanowisko jest jednak trudne do zaakceptowania. Dzisiejsza demokracja czerpie przecież swoje podstawowe ideały z dyskursów przeszłości, w których podstawową rolę odgrywała właśnie filozofia. Zerwanie z myśleniem mitycznym, irracjonalnym stało się właśnie podstawą demokracji poprzedzonej przez filozofię. Demokracja ateńska ściśle współpracowała z filozofami oświecenia greckiego. Bez refleksji filozoficznej społeczeństwa demokratyczne również nie są w stanie osiągnąć koherencji w konstruowaniu wizji świata i tracą poczucie sensu i bezpieczeństwa ${ }^{36}$. Odmawianie demokracjom prawa do szukania swych filozoficznych podstaw rodzi też niebezpieczeństwo nieodporności na antydemokratyczne ataki ugruntowane filozoficznie.

32 Podobnie w: M. Kaniowski, Państwo liberalno-demokratyczne, [w:] Neutralność światopogląowa państwa, red. E. Nowicka-Włodarczyk, Kraków 1998, s. 35.

33 Wykorzystuję tutaj rozważania M. Kaniowskiego zawarte w ibidem, s. 37.

34 J. Rawls, Teoria sprawiedliwości, przeł. M. Panufnik, J. Pasek, A. Romaniuk, Warszawa 1994.

35 Por. R. Rorty, Konsekwencje pragmatyzmu. Eseje z lat 1972-1980, przeł. C. Karkowski, Warszawa 1998, s. 214.

36 Por. R. Dahl, Democratic theory and democratic experience", [w:] Democracy and Difference, red. S. Benhabib, Princeton 1996, s. 338. 
Filozofia prawa najczęściej opiera się na filozoficznym ugruntowaniu państwa liberalno-demokratycznego, a także na jednoczesnym uznaniu, że jest ono samo przez się uzasadnione jako najbardziej racjonalna praktyka polityczna państwa.

Połączenie tych dwóch tez daje prawo do stwierdzenia, że filozofia pozostająca $\mathrm{w}$ takiej relacji do demokracji sama musi być częścią demokratycznego dyskursu. Nie ma możliwości uzasadnienia demokracji przez filozofię z zewnątrz. Akceptując wspomniany wyżej antykognitywizm, filozofia może uzasadniać demokrację tylko akceptując z kolei samą siebie jako odmianę dyskursu demokratycznego, choć jedynego, który jest w stanie brać w nawias same założenia filozofii, nie przestając być przez to dyskursem demokratycznym.

Jest to filozofia, która wspomaga demokratyczną politykę, akceptując tezę, że człowiek jako obywatel jest wrzucony w świat liberalno-demokratycznej polityki i nie zaczyna nigdy swej myśli od punktu zerowego, choćby przez to, że jego myślenie jest zawsze zapośredniczone przez język, który jest zawsze społeczny, a nigdy prywatny. Taka filozofia jest $\mathrm{w}$ istocie hermenutyką polityki. Nie dostarcza recept politycznych, lecz wprost przeciwnie: demaskuje uproszczone diagnozy i recepty ideologów, a także polityków (tych bardziej zideologizowanych). Filozofia jest ważna dla polityki, bo pozwala nam lepiej zrozumieć siebie i ludzki świat, dzięki czemu możemy poszerzyć pole publicznej dyskusji, wprowadzić nowe, bliższe potocznym intuicjom punkty widzenia, podważyć niekwestionowane dotąd kategorie dyskursu.

\section{THE METHODOLOGIES OF THE THEORY OF LAW AND THE PROBLEM OF THE POLITICAL NATURE} OF JURISPRUDENCE. BEHAVIOURAL AND INTENSIONAL ASPECTS

\section{Summary}

The paper is devoted to the problem of the impact of theory of law methodologies on the political nature of jurisprudence. The author seeks to demonstrate that some theory of law methods are more susceptible to politicisation than other. Referring to H. Hart, he introduces a distinction between the external and internal theories of law. Among the external theories he distinguishes the so-called integrating theories and cognitive theories, while dividing the internal theories into intensional and extensional, drawing on the division of interpretation theories. The author demonstrates that the so-called political nature of theories is a phenomenon most often encountered in internal and intensional approaches. In particular, theories based on the agonistic discourse concept (C. Mouffe) politicise the legal discourse by strengthening the illocutionary force of political arguments in comparison with legal arguments. Only consensual discourse concepts (R. Alexy) avoid this danger. 